

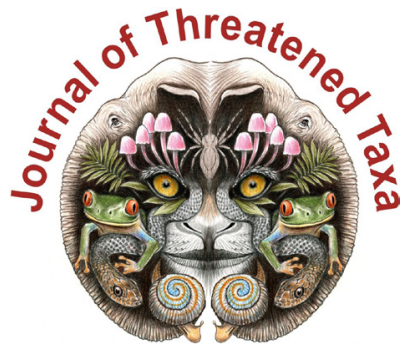

ISSN 0974-7907 (Online); ISSN $0974-7893$ (Print)

Publisher

Host

Wildlife Information Liaison Development Society

www.wild.zooreach.org

Zoo Outreach Organization www.zooreach.org

No. 12, Thiruvannamalai Nagar, Saravanampatti - Kalapatti Road, Saravanampatti, Coimbatore, Tamil Nadu 641035, India

Ph: +91 9385339863 | www.threatenedtaxa.org

Email: sanjay@threatenedtaxa.org

EDITORS

\section{Founder \& Chief Editor}

Dr. Sanjay Molur

Wildlife Information Liaison Development (WILD) Society \& Zoo Outreach Organization (ZOO),

12 Thiruvannamalai Nagar, Saravanampatti, Coimbatore, Tamil Nadu 641035, India

\section{Deputy Chief Editor}

Dr. Neelesh Dahanukar

Noida, Uttar Pradesh, India

\section{Managing Editor}

Mr. B. Ravichandran, WILD/ZOO, Coimbatore, India

\section{Associate Editors}

Dr. Mandar Paingankar, Government Science College Gadchiroli, Maharashtra 442605, India

Dr. Ulrike Streicher, Wildlife Veterinarian, Eugene, Oregon, USA

Ms. Priyanka Iyer, ZOO/WILD, Coimbatore, Tamil Nadu 641035, India

Dr. B.A. Daniel, ZOO/WILD, Coimbatore, Tamil Nadu 641035, India

\section{Editorial Board}

Dr. Russel Mittermeier

Executive Vice Chair, Conservation International, Arlington, Virginia 22202, USA

\section{Prof. Mewa Singh Ph.D., FASc, FNA, FNASc, FNAPsy}

Ramanna Fellow and Life-Long Distinguished Professor, Biopsychology Laboratory, and Institute of Excellence, University of Mysore, Mysuru, Karnataka 570006, India; Honorary Professor, Jawaharlal Nehru Centre for Advanced Scientific Research, Bangalore; and Adjunct Professor, National Institute of Advanced Studies, Bangalore

\section{Stephen D. Nash}

Scientific Illustrator, Conservation International, Dept. of Anatomical Sciences, Health Sciences Center, T-8, Room 045, Stony Brook University, Stony Brook, NY 11794-8081, USA

\section{Dr. Fred Pluthero}

Toronto, Canada

\section{Dr. Priya Davidar}

Sigur Nature Trust, Chadapatti, Mavinhalla PO, Nilgiris, Tamil Nadu 643223, India

\section{Dr. Martin Fisher}

Senior Associate Professor, Battcock Centre for Experimental Astrophysics, Cavendish

Laboratory, JJ Thomson Avenue, Cambridge CB3 OHE, UK

\section{Dr. John Fellowes}

Honorary Assistant Professor, The Kadoorie Institute, 8/F, T.T. Tsui Building, The University of Hong Kong, Pokfulam Road, Hong Kong

\section{Prof. Dr. Mirco Solé}

Universidade Estadual de Santa Cruz, Departamento de Ciências Biológicas, Vice-coordenado do Programa de Pós-Graduação em Zoologia, Rodovia Ilhéus/Itabuna, Km 16 (45662-000)

Salobrinho, Ilhéus - Bahia - Brasil

\section{Dr. Rajeev Raghavan}

Professor of Taxonomy, Kerala University of Fisheries \& Ocean Studies, Kochi, Kerala, India

\section{English Editors}

Mrs. Mira Bhojwani, Pune, India

Dr. Fred Pluthero, Toronto, Canad

Mr. P. Ilangovan, Chennai, India

Web Development

Mrs. Latha G. Ravikumar, ZOO/WILD, Coimbatore, India

\section{Typesetting}

Mr. Arul Jagadish, ZOO, Coimbatore, India

Mrs. Radhika, ZOO, Coimbatore, India

Mrs. Geetha, ZOO, Coimbatore India
Fundraising/Communications

Mrs. Payal B. Molur, Coimbatore, India

Subject Editors 2018-2020

Fungi

Dr. B. Shivaraju, Bengaluru, Karnataka, India

Dr. R.K. Verma, Tropical Forest Research Institute, Jabalpur, India

Dr. Vatsavaya S. Raju, Kakatiay University, Warangal, Andhra Pradesh, India

Dr. M. Krishnappa, Jnana Sahyadri, Kuvempu University, Shimoga, Karnataka, India

Dr. K.R. Sridhar, Mangalore University, Mangalagangotri, Mangalore, Karnataka, India

Dr. Gunjan Biswas, Vidyasagar University, Midnapore, West Bengal, India

\section{Plants}

Dr. G.P. Sinha, Botanical Survey of India, Allahabad, India

Dr. N.P. Balakrishnan, Ret. Joint Director, BSI, Coimbatore, India

Dr. Shonil Bhagwat, Open University and University of Oxford, UK

Prof. D.J. Bhat, Retd. Professor, Goa University, Goa, India

Dr. Ferdinando Boero, Università del Salento, Lecce, Italy

Dr. Dale R. Calder, Royal Ontaro Museum, Toronto, Ontario, Canada

Dr. Cleofas Cervancia, Univ. of Philippines Los Baños College Laguna, Philippines

Dr. F.B. Vincent Florens, University of Mauritius, Mauritius

Dr. Merlin Franco, Curtin University, Malaysia

Dr. V. Irudayaraj, St. Xavier's College, Palayamkottai, Tamil Nadu, India

Dr. B.S. Kholia, Botanical Survey of India, Gangtok, Sikkim, India

Dr. Pankaj Kumar, Kadoorie Farm and Botanic Garden Corporation, Hong Kong S.A.R., China

Dr. V. Sampath Kumar, Botanical Survey of India, Howrah, West Bengal, India

Dr. A.J. Solomon Raju, Andhra University, Visakhapatnam, India

Dr. Vijayasankar Raman, University of Mississippi, USA

Dr. B. Ravi Prasad Rao, Sri Krishnadevaraya University, Anantpur, India

Dr. K. Ravikumar, FRLHT, Bengaluru, Karnataka, India

Dr. Aparna Watve, Pune, Maharashtra, India

Dr. Qiang Liu, Xishuangbanna Tropical Botanical Garden, Yunnan, China

Dr. Noor Azhar Mohamed Shazili, Universiti Malaysia Terengganu, Kuala Terengganu, Malaysia

Dr. M.K. Vasudeva Rao, Shiv Ranjani Housing Society, Pune, Maharashtra, India

Prof. A.J. Solomon Raju, Andhra University, Visakhapatnam, India

Dr. Mandar Datar, Agharkar Research Institute, Pune, Maharashtra, India

Dr. M.K. Janarthanam, Goa University, Goa, India

Dr. K. Karthigeyan, Botanical Survey of India, India

Dr. Errol Vela, University of Montpellier, Montpellier, France

Dr. P. Lakshminarasimhan, Botanical Survey of India, Howrah, India

Dr. Larry R. Noblick, Montgomery Botanical Center, Miami, USA

Dr. K. Haridasan, Pallavur, Palakkad District, Kerala, India

Dr. Analinda Manila-Fajard, University of the Philippines Los Banos, Laguna, Philippines

Dr. P.A. Sinu, Central University of Kerala, Kasaragod, Kerala, India

Dr. Afroz Alam, Banasthali Vidyapith (accredited A grade by NAAC), Rajasthan, India

Dr. K.P. Rajesh, Zamorin's Guruvayurappan College, GA College PO, Kozhikode, Kerala, India

Dr. David E. Boufford, Harvard University Herbaria, Cambridge, MA 02138-2020, USA

Dr. Ritesh Kumar Choudhary, Agharkar Research Institute, Pune, Maharashtra, India

Dr. Navendu Page, Wildlife Institute of India, Chandrabani, Dehradun, Uttarakhand, India

\section{Invertebrates}

Dr. R.K. Avasthi, Rohtak University, Haryana, India

Dr. D.B. Bastawade, Maharashtra, India

Dr. Partha Pratim Bhattacharjee, Tripura University, Suryamaninagar, India

Dr. Kailash Chandra, Zoological Survey of India, Jabalpur, Madhya Pradesh, India

Dr. Ansie Dippenaar-Schoeman, University of Pretoria, Queenswood, South Africa

Dr. Rory Dow, National Museum of natural History Naturalis, The Netherlands

Dr. Brian Fisher, California Academy of Sciences, USA

Dr. Richard Gallon, llandudno, North Wales, LL30 1UP

Dr. Hemant V. Ghate, Modern College, Pune, India

Dr. M. Monwar Hossain, Jahangirnagar University, Dhaka, Bangladesh

Mr. Jatishwor Singh Irungbam, Biology Centre CAS, Branišovská, Czech Republic.

Dr. Ian J. Kitching, Natural History Museum, Cromwell Road, UK

Dr. George Mathew, Kerala Forest Research Institute, Peechi, India

For Focus, Scope, Aims, and Policies, visit https://threatenedtaxa.org/index.php/JoTT/aims_scope
For Article Submission Guidelines, visit https://threatenedtaxa.org/index.php/JoTT/about/submissions
For Policies against Scientific Misconduct, visit https://threatenedtaxa.org/index.php/JoTT/policies_various

continued on the back inside cover 


\title{
A rare photographic record of Eurasian Otter Lutra lutra with a note on its habitat from the Bhagirathi Basin, western Himalaya, India
}

\author{
Ranjana Pal ${ }^{1}(\mathbb{D})$, Aashna Sharma ${ }^{2}(\mathbb{D})$, Vineet Kumar Dubey ${ }^{3}$ (D), Tapajit Bhattacharya ${ }^{4}$ (D), \\ Jeyaraj Antony Johnson ${ }^{5}$ (D), Kuppusamy Sivakumar ${ }^{6}$ (i) \& Sambandam Sathyakumar ${ }^{7}$ (iD \\ 1,2,3,5,6,7 Wildlife Institute of India, Chandrabani, Dehradun 248001, Uttarakhand, India. \\ ${ }^{4}$ Durgapur Government College, Durgapur, West Bengal 713214, India. \\ ${ }^{1}$ ranjana.biocon@gmail.com, ${ }^{2}$ aashna.wildlife@gmail.com, ${ }^{3}$ vineetkrdubey@gmail.com, ${ }^{4}$ tapajit@gmail.com , ${ }^{5}$ jaj@wii.gov.in, \\ ${ }^{6}$ ksivakumar@wii.gov.in, ${ }^{7}$ ssk@wii.gov.in (corresponding author)
}

\begin{abstract}
The Eurasian Otter Lutra lutra is an elusive, solitary anima that has one of the widest distributions of all palearctic mammals. Once widely distributed in Asia, the Eurasian Otter population is now vulnerable to urbanization, pollution, poaching, and dam construction. Eurasian Otter distribution in the Indian Himalayan rivers is little explored, and information from this high-altitude riverine ecosystem is sparse. This publication reports a rare photographic record of the Eurasian Otter which confirms its presence in the high-altitude temperate forest of the Upper Bhagirathi Basin, western Himalayan region. The otter was recorded during investigations of terrestrial and aquatic fauna in the Bhagirathi Basin $\left(7,586 \mathrm{~km}^{2}, 500-5,000 \mathrm{~m}\right)$ of Uttarakhand State, India from October 2015 to May 2019. Among aquatic fauna, Brown Trout were found to be abundant in high altitude river stretches, with a catch per unit effort of $1.02 \mathrm{~kg} \mathrm{~h}^{-1}$. Additionally, 26 families of freshwater macroinvertebrates underscored a rich diet available for the Brown Trout, which in turn is a potential food source for the otters. The riverine ecosystem is undergoing dramatic changes because of the increasing demand for hydropower plants in the Bhagirathi Basin. Although mitigation measures are currently in place for fish, the presence of otters further necessitates the need for targeted management for high-altitude Himalayan rivers. There
\end{abstract}

is an imperative need for intensive otter surveys using methods such as camera traps in riparian habitats along the Bhagirathi River and its tributaries.

Keywords: Anthropogenic pressures, camera trapping, hydropower projects, otter, riverine ecosystem.

Information on otters of the high-altitude riverine ecosystems in the Indian Himalayan region is lacking. Eurasian Otter Lutra lutra (Linnaeus, 1758), is the only otter found in high altitude ( $>2,000 \mathrm{~m}$ ) mountain streams and rivers (Prater 1971). The species has the widest distributions of all palearctic mammals (Corbet 1966); however, due to human pressures, they have disappeared from most of their range (Yoxon \& Yoxon 2019). There is lack of information about its population status in Asia,

Citation: Pal, R., A. Sharma, V.K. Dubey, T. Bhattacharya, J.A. Johnson, K. Sivakumar \& S Sathyakumar (2021). A rare photographic record of Eurasian Otter Lutra lutra with a note on its habitat from the Bhagirathi Basin, western Himalaya, India. Journal of Threatened Taxa 13(13): 20072-20077. https://doi.org/10.11609/ jott.6937.13.13.20072-20077

Copyright: (C) Pal et al. 2021. Creative Commons Attribution 4.0 International License. JoTT allows unrestricted use, reproduction, and distribution of this article in any medium by providing adequate credit to the author(s) and the source of publication.

Funding: Department of Science and Technology (DST), Government of India, National Mission for Sustaining Himalayan Ecosystem (NMSHE), Grant No. DST/SPLICE/CCP/NMSHE/TF-2/WII/2014/[G].

Competing interests: The authors declare no competing interests.

Acknowledgements: This work is part of project initiated under the National Mission for Sustaining the Himalayan Ecosystem Programme funded by the Department of Science and Technology, Government of India under grant no. DST/SPLICE/CCP/NMSHE/TF-2/WII/2014[G]. We are thankful to the director and dean, Wildlife Institute of India, for their guidance and support. We are grateful to Mr. D.V.S. Khati, principal chief conservator of forests and chief wildlife warden, Uttarakhand, for granting us the research permission and Mr. Shrawan Kumar, Mr. N.B. Sharma, deputy director, Gangotri National Park, and Mr. Sandeep Kumar, divisional forest officer, Uttarkashi, for providing necessary support and cooperation. We thank Dr. S.A. Hussain and Ms. Sayanti Basak for their help in identification of the species.
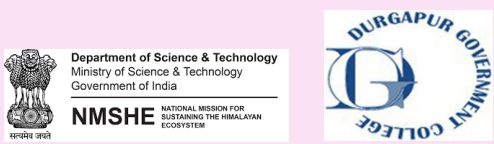
where it is believed to be under tremendous pressure because of poaching (Roos et al. 2015). The species is classified as 'Near Threatened' on the IUCN Red List, and is vulnerable to the pelt trade (Roos et al. 2015), climate change (Gupta et al. 2020), and habitat destruction \& pollution (Roos et al. 2015). It is listed in Appendix I of CITES, and in India, is listed in Schedule II (Part 2) of the Wildlife (Protection) Act, 1972.

Scattered records across Asia are indicative of otter distribution along all the major river systems, ranging to the southernmost parts of Sumatra, Indonesia (Corbet \& Hill 1992). However, its distributional range in the Indian Himalayan region is still unclear, with research suggesting that it is mostly confined to river plains and foothills (Atkinson 1882; Hussain 2002) with the exception of a few high-altitude records from the Trans-Himalayan regions of Ladakh and Himachal Pradesh (Conroy et al. 1998). The earliest records of otter from the state of Uttarakhand (Atkinson 1882) date to the $19^{\text {th }}$ century, when they were recorded from the Ramganga River and Dehradun. According to Atkinson (1882), the Eurasian Otter was found throughout the Terai and in all the larger streams along the Himalayan foothill. Apart from its distribution in the Indian Himalayan region, this species has been recorded from the northern mountainous region of Pakistan and Punatshanghchu basin of Bhutan (Yoxon \& Yoxon 2019). There are no recent confirmed records of the Eurasian Otter from Nepal (Yoxon \& Yoxon 2019). Based on their distribution records from mountainous habitats in neighbouring regions (Image 1), their presence was long anticipated in the high-altitude river systems of Uttarakhand state. However, studies in low elevation areas have indicated that otters have declined drastically from most stretches of the rivers in Uttarakhand due to habitat loss/degradation caused by hydropower projects, anthropogenic pressures, and poaching (Nawab 2008; Chopra et al. 2014). Recent attempts to confirm otter presence in lower part of Bhagirathi and adjacent Alaknanda basin using sign surveys yielded no sightings or any indirect evidence of their presence, although suitable habitats were found in both the basins (Hussain 2002; Rajvanshi et al. 2012).

Here, we report a photographic record of Eurasian Otter from the high-altitude temperate forest of the Upper Bhagirathi River Basin, Uttarakhand state. The study is the part of a long-term monitoring of wild flora and fauna under the National Mission for Sustaining the Himalayan Ecosystem (NMSHE) project (Task force IV). Surveys were carried out in different areas of Bhagirathi Basin $\left(7,586.71 \mathrm{~km}^{2}\right)$, to develop baseline information on faunal species of terrestrial and aquatic components. Based on their records specifically from the high-elevations in other basins of Himalaya, we also aimed to understand the habitat availability in our study area, as well as the potential faunal composition which supports the dietary needs of the Eurasian Otter in such landscapes. As such the camera trapping surveys were paralleled with the aquatic habitat, fish and macroinvertebrate faunal surveys to investigate the reasons dictating their rare preference for the highelevation streams and rivers of Himalaya.

\section{MATERIALS AND METHOdS}

The Bhagirathi is a large glacial fed and turbulent Himalayan river that emerges from Gangotri glacier (Gaumukh), $30.925^{\circ} \mathrm{N} \& 79.082^{\circ} \mathrm{E}$ at an elevation of $3,812 \mathrm{~m}$. The valley has a broad U-shape at higher elevations characteristic of glacial origin, but at lower elevations the river has cut a narrow V-shaped fluvial valley. Along the $217 \mathrm{~km}$ long river the elevation ranges from $480 \mathrm{~m}$ to $3,200 \mathrm{~m}$ with an average gradient of $1.25 \%$ (Rajvanshi et al. 2012). The basin encompasses diverse habitats: tropical and sub-tropical forests (500-1,200 $\mathrm{m})$, temperate forests $(1,200-2,800 \mathrm{~m})$, sub-alpine forests $(2,900-3,200 \mathrm{~m})$, alpine scrub and meadows above 3,200 m (Rajwar 1993). Human habitations in the study area are confined below the elevation of 3,000 m (Image 1).

Data on the seasonal distribution of mammal species were collected using camera traps (Cuddeback C1, WI, USA) from October 2015 to March 2019 broadly covering two seasons: summer and winter. Camera trapping was carried out in two stages. In the first stage (October 2015-September 2017), preliminary survey for all the mammals was carried out along the elevation gradient of $500 \mathrm{~m}$ to $5,200 \mathrm{~m}$. At each site, camera traps were deployed in locations likely to be used by animals inside the forest, alpine meadows, along the river beds and other such microhabitats (Sathyakumar et al. 2013). In the second stage (October 2017 to March 2019), camera traps exercise was carried out only in the high elevation habitats ( $2500 \mathrm{~m}$ to $5200 \mathrm{~m}$ ) targeting Snow Leopard Panthera uncia, Leopard Panthera pardus, and their prey species. To survey evenly across the various habitats, we divided the basin into $16 \times 16 \mathrm{~km}$ grids, which corresponds to the average home range of the largest mammal in the area, the Himalayan Brown Bear Ursus arctos isabellinus. We subdivided these cells into $4 \times 4 \mathrm{~km}$ (first stage) and $3 \times 3 \mathrm{~km}$ cells (second stage) deployed camera traps in 3-6 of these smaller cells within each $16 \times 16$ cell. A total of 318 locations were sampled during this period (Image 1 ). 


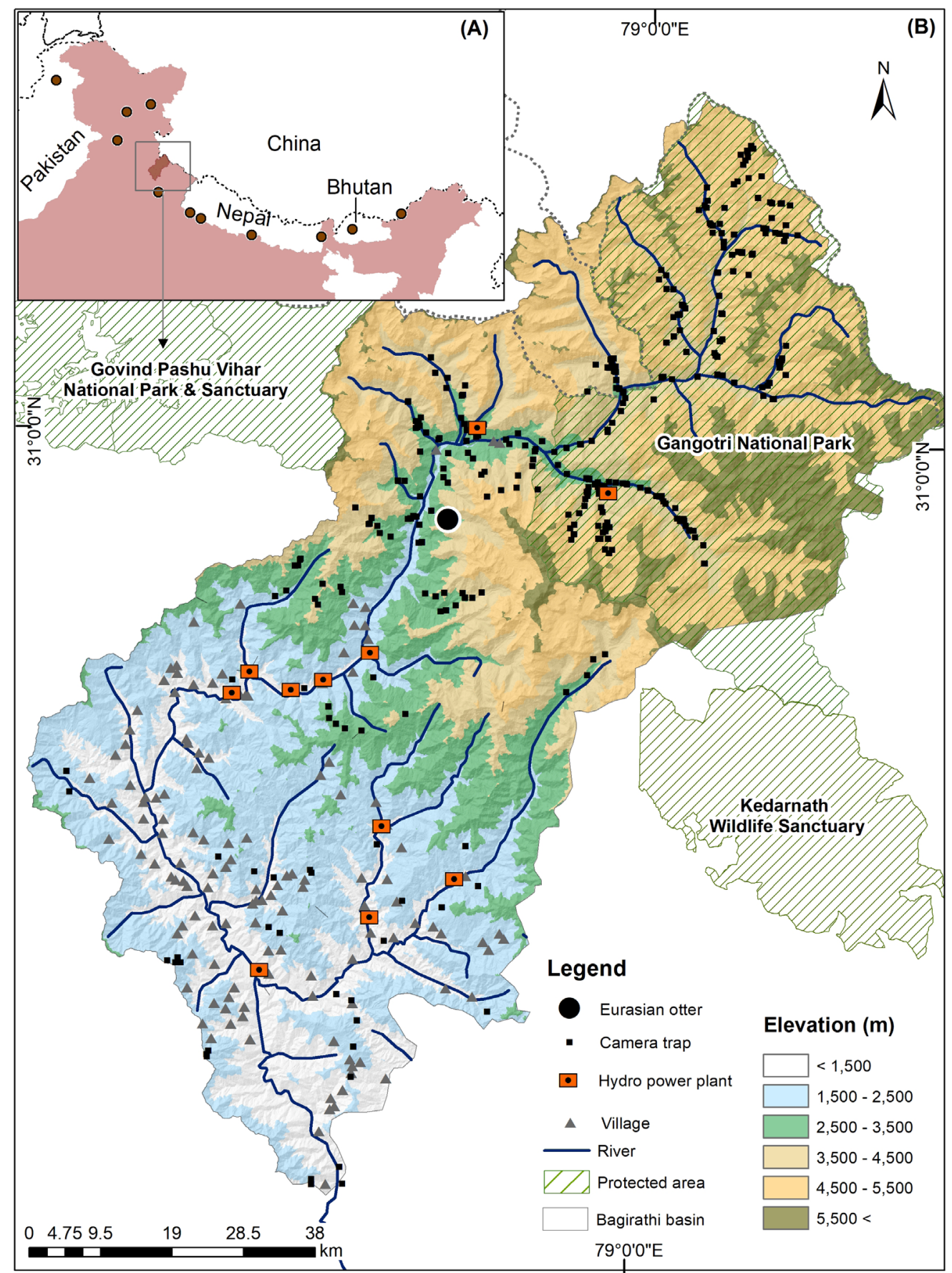

Image 1. A-Map showing location of the Bhagirathi Basin. The red points show the recent confirmed records from different Himalayan regions I B-Map showing distribution of camera trapping locations along the Bhagirathi Basin and Eurasian Otter captured location.

Simultaneously, fish and macroinvertebrate sampling was also conducted in the river stretches of Bhagirathi Basin. Rivers were sampled from March 2016 to December 2018 at every $500 \mathrm{~m}$ for the higher-order streams ( $4^{\text {th }}$ and higher) and $200 \mathrm{~m}$ interval for the lower order streams ( $3^{\text {rd }}$ and lower). This method was followed to target equivalent representation of all streams, as the lower order streams often did not extend more than $500 \mathrm{~m}$ in length (Sharma et al. 2021). In total, $38.92 \mathrm{~km}$ of river stretch was sampled with a total of 51 sampling points spanning across the Bhagirathi River and three of its major tributaries Kakori, Jalandhari, and Sian using cast nets for fishes and D-frame dip net for macroinvertebrates. The catch per unit effort (CPUE) of 
the cast net was calculated by dividing the catch of each sampling site by the number of hours fished (Morgan \& Burgess 2005). The fishes were caught and released post-sampling. The water quality parameters were recorded using a multi-parameter water monitoring kit, while the microhabitat characterization was done based on Bain \& Stevenson (1999).

\section{RESULTS}

Camera trapping effort (78,828 trap nights) across the basin resulted in 28,257 captures of different mammal species. Excluding Eurasian Otter, a total of 39 species of mammals were recorded during the survey belonging to 13 families in five orders (Pal et al. 2020). A solitary otter was likely first photo-captured on 25 September 2018 at 1352 h, although the species could not be definitively identified as the capture was too close to the camera. Another photo of an individual was captured on 14 February 2019 at $0546 \mathrm{~h}$ (Image 2). Based on the characteristic features such as the conical tail, lighter underside, the bare and black rhinarium with a W-shaped upper margin, the otter species was confirmed as the Eurasian Otter (Hussain 2013; Menon 2014). Along with photographic capture we also captured a 30-sec video recording, where the otter was observed moving on snow. The species is known to survive in extreme cold conditions and has previously been reported at an elevation of 3,700 $\mathrm{m}$ in the Himalaya (Prater 1971) and up to 4,120 $m$ in Tibet (Mason \& Macdonald 1986).

An image of the Eurasian Otter was captured near the Dabrani region, which is the confluence point of Jaulighad, and Songhad tributaries with Bhagirathi River. It was captured at an elevation of $2,700 \mathrm{~m}$ near the bank of Jualighad approximately two km away from its confluence with the main river. The area is characterized by highly rugged mountainous terrain (Image 2). The river forms a deep constricted V-shaped valley in Dabrani together with a high runoff and steep gradient. The area where the otter was captured is characterized by big rocks, boulder fields, and deep crevices. Such habitats are considered as ideal denning and breeding sites for the Eurasian Otters (Hussain 2013). Dense bankside vegetation is also an important determinant of otter's presence as crucial resting sites (Kruuk 2006). The vegetation in the area where otter was photocaptured is a dense temperate riverine habitat with steep slopes covered with conifer- broadleaved mixed forests characterized by the presence of tree species such as Alnus nepalensis, Betula alnoides, and Cedrus deodara. The habitat in the upstream river changes to sub-alpine where species such as Rhododendron sp. and Pinus wallichiana are found. Other mammals recorded from the same location are common leopard, Himalayan Goral Nemorhaedus goral, Himalayan Tahr Hemitragus jemlahicus, Himalayan Serow Capricornis thar, Himalayan Langur Semnopithecus schistaceus, and Yellow-throated Marten Martes flavigula.

Adapted for a semi-aquatic life, Eurasian Otters are primarily piscivorous with fish contributing $80 \%$ of their diet (Webb 1975; Ruiz-Olmo \& Palazon 1997). Throughout our surveys we found the exotic Brown Trout Salmo trutta to be the only fish species inhabiting elevations above 2,500 m, with a CPUE of $1.02 \mathrm{~kg} \mathrm{~h}^{-1}$ ranging between 0.22 to $2.65 \mathrm{~kg} \mathrm{hr}^{-1}$ across all the sampling locations. As accounted for in our surveys, the high elevation streams $(>2,500 \mathrm{~m})$ of Bhagirathi Basin comprise 26 families of macroinvertebrates most of which belong to the Order Trichoptera, which is considered as a major diet of the Brown Trout (Fochetti et al. 2003). This underscores a habitat rich in diet for sustenance of the Brown Trout, which in turn could be a potential food source for the Eurasian Otter in the high elevation river stretches. The aquatic habitat in the highelevation basin was characterized with dissolved oxygen $(8.65 \pm 0.59 \mathrm{mg} / \mathrm{l})$ and total dissolved solids $(44.72 \pm 20.02$ $\mathrm{ppm}$ ) with a low water temperature $\left(7.55 \pm 3.09{ }^{\circ} \mathrm{C}\right)$ across the sampling duration supporting the sustenance of Brown Trout. The water flow was recorded to be swift across the width of the river ranging between 1.5 to 4.4 $\mathrm{ms}^{-1}$ with a microhabitat predominantly defined by fast flowing cascades, runs and rapids. Further, the Eurasian Otters are known to move large distances (adult male: $38.8 \pm 23.4$; adult female: $18.7 \pm 3.5 \mathrm{~km}$ ) (Durbin 1998; Green et al. 1984; Kruuk et al. 1993; Kruuk 1995) along the length of the river (which possibly include lower elevations). As such, other studies documenting the presence of fish species such as Pseudecheneis sulcata, Tor tor, Schizothorax richardsonii, Opsarius bendelisis and loaches of the genus Schistura possibly indicate a rich ichthyofaunal diet for the Eurasian Otter (Rajvanshi et at. 2012). It thus makes it evident that the potential food available for Eurasian Otter has been identified along the stretches of Bhagirathi River and necessitates the need for more surveys to document Eurasian Otters in the Himalayan region.

\section{Discussion}

In a four year effort, Otters were recorded only twice. Although a large network of camera traps was used in the study, very few were deployed near rivers or streams. Of 318 cameras deployed in the basin, only five cameras placed within $1 \mathrm{~km}$ distance from the river 

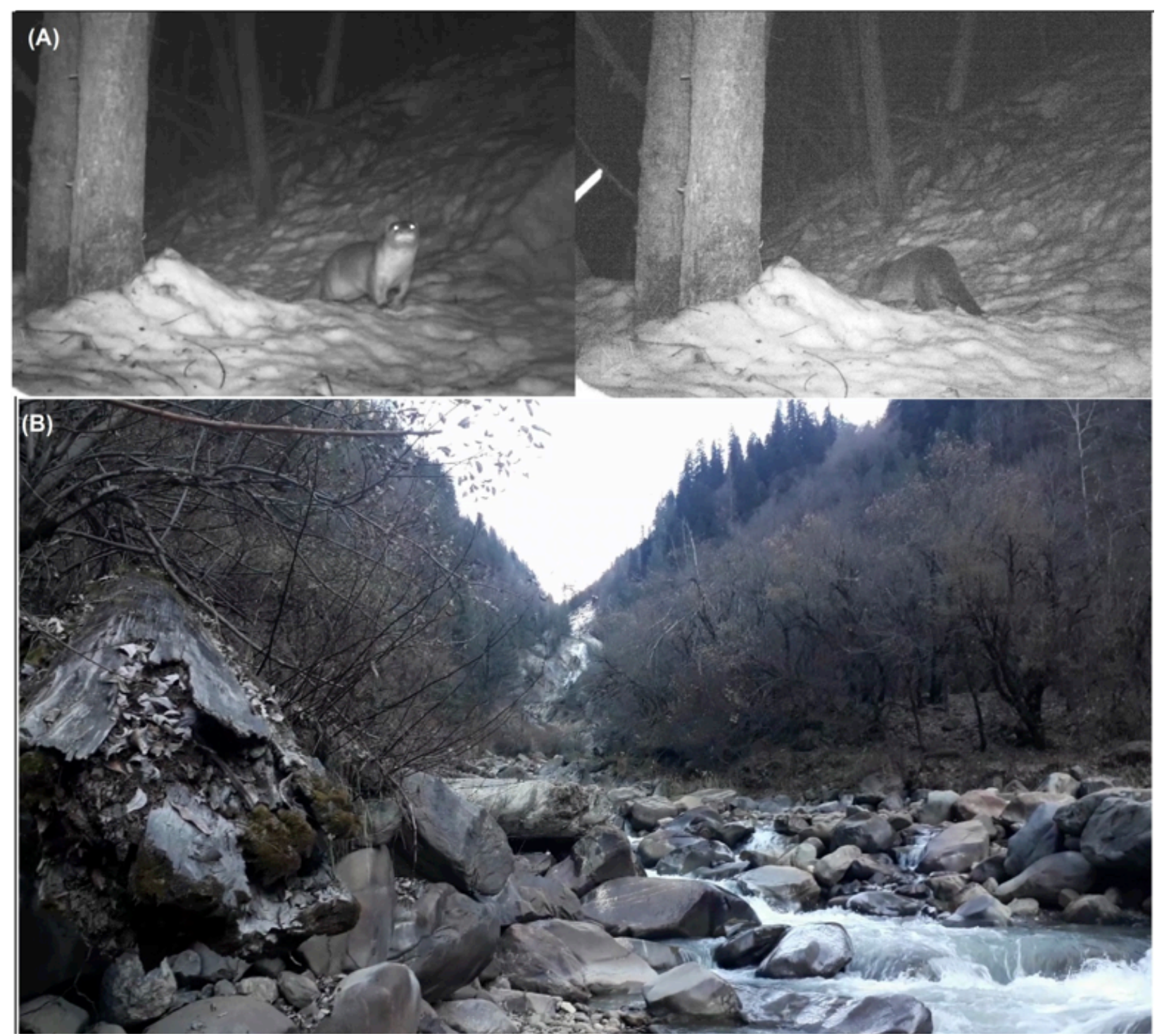

Image 2. A-A solitary Eurasian Otter was captured at an elevation of 2,700 m near the bank of Jualighad, a tributary of the Bhagirathi River. The area is characterized by highly rugged mountainous terrain (@ WII_DST-NMSHE camera trap) | B-The vegetation in the area is a temperate riverine habitat with steep slopes covered with conifer- broadleaved mixed forests (๑ Ranjana Pal).

or stream. Otters may have been present in deep gorge areas, but as the sites were inaccessible they could not be sampled. Otter presence often goes unnoticed because of their elusive, solitary, and nocturnal habits. We recommend more dedicated surveys using camera traps to understand the status and distribution of Eurasian Otter in the region. A large chain of tributaries supports Bhagirathi; most of them are still in pristine conditions. Additionally, their presence should be explored in the similar habitat in other catchments of Uttarakhand. There is an urgent need to understand the scattered population of Eurasian Otter in order to effectively protect this species. Removal of bank sidevegetation, construction of dams, draining of wetlands, aquaculture, and associated human-made impacts are some of the potential threats to Eurasian Otters (Roos et al. 2015). Dams have further been implicated in the decline of the Eurasian Otter (Foster-Turley et al. 1990; Macdonald \& Mason 1994).

Currently the Bhagirathi River is dammed at 11 locations (Image 1), which has changed the hydro geomorphology of the river. The river has been altered drastically from a swiftly flowing stretch (due to steep gradient) into a vast stretch of semi stagnant water with a characteristic flat gradient and large volumes of water (Agarwal et al. 2018). Fish diversity in Bhagirathi River is also currently declining and is threatened by blockage of migration routes, disconnection of 
the river and floodplain, changes in flow regime, change in physiochemical attributes (Agarwal et al. 2018). Destructive fishing practices in the lower order tributaries of the Bhagirathi, which are potential spawning grounds and nursery sites for many coldwater fish, are risking the viability of the fish populations imperative for the otter's diet. In addition to the existing pressures on the aquatic ecosystem, there are four more dams commissioned, one under construction and one proposed hydropower project in Bhagirathi River, which will potentially affect $70 \%$ of river length (Chopra et al. 2014). While mitigation strategies are currently being adapted to reduce impact on fish, otter presence further necessitates targeted management for the highaltitude Himalayan rivers. Mitigation strategies need to be revised to include a wider range of flora $\&$ fauna and consider the impact on the riparian ecosystem.

\section{REFERENCES}

Agarwal, N.K., G. Singh, H. Singh, N. Kumar \& U.S. Rawat (2018) Ecological impacts of dams on the fish diversity of Bhagirathi River in Central Himalaya (India). Journal of Coldwater Fisheries 1(1): 74-84

Atkinson, E.T. (1882). The Himalayan Gazetteer, 3 vols, reprinted 1989. Cosmo Publications, New Delhi, 2,631pp.

Bain, M.B \& N.J. Stevenson (1999). Aquatic habitat assessment. American Fisheries Society, Bethesda, MD, United States, 224pp.

Chopra, R., B.P. Das, H. Dhyani, A. Verma, H.S. Venkatesh, H.B. Vasistha, D.P. Dobhal, N. Juyal, S. Sathyakumar, S. Pathak \& T.K.S. Chauhan (2014). Assessment of environmental degradation and impact of hydroelectric projects during the June 2013 disaster in Uttarakhand. Part I-Main Report. Submitted for publication to The Ministry of Environment and Forests Government of India, 226pp.

Conroy, J., R. Melisch \& P. Chanin (1998). The distribution and status of the Eurasian Otter (Lutra lutra) in Asia-a preliminary review. IUCN Otter Specialist Group Bulletin 15(1): 15-30.

Corbet, G.B. \& J.E. Hill (1992). The Mammals of the Indomalayan Region: A Systematic Review. Oxford University Press, Oxford, 488pp.

Corbet, G.H. (1966). The Terrestrial Mammals of Western Europe. Foulis, London, 264pp.

Durbin, L.S. (1998). Habitat selection by five otters Lutra lutra in rivers of northern Scotland. Journal of Zoology 245: 85-92. https://doi. org/10.1111/j.1469-7998.1998.tb00075.x

Fochetti, R., Amici, I. \& Argano, R. (2003). Seasonal changes and selectivity in the diet of brown trout in the River Nera (Central Italy). Journal of Freshwater Ecology 18(3): 437-444. https://doi.org/10.1 080/02705060.2003.9663979

Foster-Turley, P., S.M. Macdonald \& C.F. Mason (Eds) (1990). Otters: an action plan for their conservation. International Union for Conservation of Nature and Natural Resources, Gland, Switzerland, 126pp. https://doi.org/10.2305/IUCN.CH.1990.SSC-AP.3.en

Green, J., R. Green \& D.J. Jefferies (1984). A radio-tracking survey of otters Lutra lutra on a Perthshire river system. Lutra 27: 85-145.

Gupta, N., V. Tiwari, M. Everard, M. Savage, S.A. Hussain, M.A Chadwick, J.A. Johnson \& V.K. Belwal (2020). Assessing the distribution pattern of otters in four rivers of the Indian Himalayan biodiversity hotspot. Aquatic Conservation: Marine and Freshwater Ecosystems 30(3): 601-610. https://doi.org/10.1002/aqc.3284

Hussain, S.A. (2002). A note on the historical records of otter distribution in India, with special reference to Lower Himalayas and Terai. In: Proceedings of the $7^{\text {th }}$ international otter colloquium, otter conservation-an example for a sustainable use of wetlands. IUCN Otter Specialist Group Bulletin 19: 131-142.

Hussain, S.A. (2013). Otters, pp. 392-415. In: Johnsingh, A.J.T. \& N. Manjrekar (eds). Mammals of South Asia, Volume 1. Universities Press, India, 694pp.

Kruuk, H. (1995). Wild Otters: Predation and Populations. Oxford University Press, Oxford, 290 pp.

Kruuk, H. (2006). Otters: Ecology, Behaviour and Conservation. Oxford University Press, 265pp. https://doi.org/10.1093/acprof:o so/9780198565871.001.0001

Kruuk, H., D.N. Carss, J.W.H. Conroy \& L. Durbin (1993). Otter (Lutra lutra L.) numbers and fish productivity in rivers in N.E. Scotland. Symposia of the Zoological Society of London 65: 171-191.

Macdonald, S.M. \& C.F. Mason (1994). Status and conservation needs of the otter (Lutra lutra) in the western Palaearctic. Nature and Environment. Council of Europe, Strasbourg, 54pp.

Mason, C.F. \& S.M. Macdonald (1986). Otters: Ecology and Conservation. Cambridge University Press, Cambridge, 248pp.

Menon, V. (2014). Indian Mammals: A Field Guide. Hachette India, Gurgaon, 528pp.

Morgan, A.C. \& G.H. Burgess (2005). Fishery-dependent sampling: total catch, effort and catch composition, pp. 182-200. In: Musick, J.A. \& R. Bonfil (eds.). Management techniques for elasmobranch fisheries. Fisheries Technical Paper 474, FAO, Rome.

Nawab, A. (2008). Conservation of otter species in India. Interim Field Report: Narora (Ramsar Site), Uttar Pradesh. Freshwater \& Wetlands Programme, WWF-India, New Delhi, 10pp.

Pal, R., S. Thakur, S. Arya, T. Bhattacharya \& S. Sathyakumar (2020). Mammals of the Bhagirathi Basin, Western Himalaya: understanding distribution along spatial gradients of habitats and disturbances. Oryx 55(5): 1-11. https://doi.org/10.1017/ S0030605319001352

Prater, S.H. (1971). The Book of Indian Animals. Bombay Natural History Society, Bombay, 348pp.

Rajvanshi, A., R. Arora, V.B. Mathur, K. Sivakumar, S. Sathyakumar, G.S. Rawat, J.A. Johnson, K. Ramesh, N. Dimri \& A. Maletha (2012). Assessment of cumulative impacts of hydroelectric projects on aquatic and terrestrial biodiversity in Alaknanda and Bhagirathi Basins, Uttarakhand. Technical Report, Wildlife Institute of India, Dehradun, India 203pp.

Rajwar, G.S. (1993). Garhwal Himalayas Ecology and Environment. Ashish Publishing house, New Delhi, 263pp.

Roos, A., A. Loy, P. de Silva, P. Hajkova \& B. Zemanová (2015). Lutra lutra. The IUCN Red List of Threatened Species 2015: e.T12419A21935287. Downloaded on 10 July 2020. https://doi. org/10.2305/IUCN.UK.2015-2.RLTS.T12419A21935287.en

Ruiz-Olmo, J. \& S. Palazón (1997). The diet of the European Otter (Lutra lutra L., 1758) in Mediterranean freshwater habitats. Journal of Wildlife Research 2(2): 171-181.

Sharma, A., V.K. Dubey, J.A. Johnson, Y.K. Rawal \& K. Sivakumar (2021). Introduced, invaded and forgotten: allopatric and sympatric native snow trout life-histories indicate brown trout invasion effects in the Himalayan hinterlands. Biological Invasions 23: 1497-1515. https://doi.org/10.1007/s10530-020-02454-8

Webb, J.B. (2009). Food of the otter (Lutra lutra) on the Somerset levels. Journal of Zoology 177(4): 486-491. https://doi. org/10.1111/j.1469-7998.1975.tb02249.x

Yoxon, P. \& B. Yoxon (2019). Eurasian Otter (Lutra lutra): A review of the current world status. Otter. Journal of the International Otter Survival Fund 5: 5-37. 
Dr. John Noyes, Natural History Museum, London, UK

Dr. Albert G. Orr, Griffith University, Nathan, Australia

Dr. Sameer Padhye, Katholieke Universiteit Leuven, Belgium

Dr. Nancy van der Poorten, Toronto, Canada

Dr. Kareen Schnabel, NIWA, Wellington, New Zealand

Dr. R.M. Sharma, (Retd.) Scientist, Zoological Survey of India, Pune, India

Dr. Manju Siliwal, WILD, Coimbatore, Tamil Nadu, India

Dr. G.P. Sinha, Botanical Survey of India, Allahabad, India

Dr. K.A. Subramanian, Zoological Survey of India, New Alipore, Kolkata, India

Dr. P.M. Sureshan, Zoological Survey of India, Kozhikode, Kerala, India

Dr. R. Varatharajan, Manipur University, Imphal, Manipur, India

Dr. Eduard Vives, Museu de Ciències Naturals de Barcelona, Terrassa, Spain

Dr. James Young, Hong Kong Lepidopterists' Society, Hong Kong

Dr. R. Sundararaj, Institute of Wood Science \& Technology, Bengaluru, India

Dr. M. Nithyanandan, Environmental Department, La Ala Al Kuwait Real Estate. Co. K.S.C.,

Kuwait

Dr. Himender Bharti, Punjabi University, Punjab, India

Mr. Purnendu Roy, London, UK

Dr. Saito Motoki, The Butterfly Society of Japan, Tokyo, Japan

Dr. Sanjay Sondhi, TITLI TRUST, Kalpavriksh, Dehradun, India

Dr. Nguyen Thi Phuong Lien, Vietnam Academy of Science and Technology, Hanoi, Vietnam

Dr. Nitin Kulkarni, Tropical Research Institute, Jabalpur, India

Dr. Robin Wen Jiang Ngiam, National Parks Board, Singapore

Dr. Lional Monod, Natural History Museum of Geneva, Genève, Switzerland.

Dr. Asheesh Shivam, Nehru Gram Bharti University, Allahabad, India

Dr. Rosana Moreira da Rocha, Universidade Federal do Paraná, Curitiba, Brasi

Dr. Kurt R. Arnold, North Dakota State University, Saxony, Germany

Dr. James M. Carpenter, American Museum of Natural History, New York, USA

Dr. David M. Claborn, Missouri State University, Springfield, USA

Dr. Kareen Schnabel, Marine Biologist, Wellington, New Zealand

Dr. Amazonas Chagas Júnior, Universidade Federal de Mato Grosso, Cuiabá, Brasil

Mr. Monsoon Jyoti Gogoi, Assam University, Silchar, Assam, India

Dr. Heo Chong Chin, Universiti Teknologi MARA (UiTM), Selangor, Malaysia

Dr. R.J. Shiel, University of Adelaide, SA 5005, Australia

Dr. Siddharth Kulkarni, The George Washington University, Washington, USA

Dr. Priyadarsanan Dharma Rajan, ATREE, Bengaluru, India

Dr. Phil Alderslade, CSIRO Marine And Atmospheric Research, Hobart, Australia

Dr. John E.N. Veron, Coral Reef Research, Townsville, Australia

Dr. Daniel Whitmore, State Museum of Natural History Stuttgart, Rosenstein, Germany.

Dr. Yu-Feng Hsu, National Taiwan Normal University, Taipei City, Taiwan

Dr. Keith V. Wolfe, Antioch, California, USA

Dr. Siddharth Kulkarni, The Hormiga Lab, The George Washington University, Washington,

D.C., USA

Dr. Tomas Ditrich, Faculty of Education, University of South Bohemia in Ceske

Budejovice, Czech Republic

Dr. Mihaly Foldvari, Natural History Museum, University of Oslo, Norway

Dr. V.P. Uniyal, Wildlife Institute of India, Dehradun, Uttarakhand 248001, India

Dr. John T.D. Caleb, Zoological Survey of India, Kolkata, West Bengal, India

Dr. Priyadarsanan Dharma Rajan, Ashoka Trust for Research in Ecology and the Environment

(ATREE), Royal Enclave, Bangalore, Karnataka, India

\section{Fishes}

Dr. Neelesh Dahanukar, IISER, Pune, Maharashtra, India

Dr. Topiltzin Contreras MacBeath, Universidad Autónoma del estado de Morelos, México

Dr. Heok Hee Ng, National University of Singapore, Science Drive, Singapore

Dr. Rajeev Raghavan, St. Albert's College, Kochi, Kerala, India

Dr. Robert D. Sluka, Chiltern Gateway Project, A Rocha UK, Southall, Middlesex, UK

Dr. E. Vivekanandan, Central Marine Fisheries Research Institute, Chennai, India

Dr. Davor Zanella, University of Zagreb, Zagreb, Croatia

Dr. A. Biju Kumar, University of Kerala, Thiruvananthapuram, Kerala, India

Dr. Akhilesh K.V., ICAR-Central Marine Fisheries Research Institute, Mumbai Research

Centre, Mumbai, Maharashtra, India

Dr. J.A. Johnson, Wildlife Institute of India, Dehradun, Uttarakhand, India

Amphibians

Dr. Sushil K. Dutta, Indian Institute of Science, Bengaluru, Karnataka, India

Dr. Annemarie Ohler, Muséum national d'Histoire naturelle, Paris, France

\section{Reptiles}

Dr. Gernot Vogel, Heidelberg, Germany

Dr. Raju Vyas, Vadodara, Gujarat, India

Dr. Pritpal S. Soorae, Environment Agency, Abu Dubai, UAE.

Prof. Dr. Wayne J. Fuller, Near East University, Mersin, Turkey

Prof. Chandrashekher U. Rivonker, Goa University, Taleigao Plateau, Goa. India

Dr. S.R. Ganesh, Chennai Snake Park, Chennai, Tamil Nadu, India

Dr. Himansu Sekhar Das, Terrestrial \& Marine Biodiversity, Abu Dhabi, UAE
Birds

Dr. Hem Sagar Baral, Charles Sturt University, NSW Australia

Dr. Chris Bowden, Royal Society for the Protection of Birds, Sandy, UK

Dr. Priya Davidar, Pondicherry University, Kalapet, Puducherry, India

Dr. J.W. Duckworth, IUCN SSC, Bath, UK

Dr. Rajah Jayapal, SACON, Coimbatore, Tamil Nadu, India

Dr. Rajiv S. Kalsi, M.L.N. College, Yamuna Nagar, Haryana, India

Dr. V. Santharam, Rishi Valley Education Centre, Chittoor Dt., Andhra Pradesh, India

Dr. S. Balachandran, Bombay Natural History Society, Mumbai, India

Mr. J. Praveen, Bengaluru, India

Dr. C. Srinivasulu, Osmania University, Hyderabad, India

Dr. K.S. Gopi Sundar, International Crane Foundation, Baraboo, USA

Dr. Gombobaatar Sundev, Professor of Ornithology, Ulaanbaatar, Mongolia

Prof. Reuven Yosef, International Birding \& Research Centre, Eilat, Israel

Dr. Taej Mundkur, Wetlands International, Wageningen, The Netherlands

Dr. Carol Inskipp, Bishop Auckland Co., Durham, UK

Dr. Tim Inskipp, Bishop Auckland Co, Durham, UK

Dr. V. Gokula, National College, Tiruchirappalli, Tamil Nadu, India

Dr. Arkady Lelej, Russian Academy of Sciences, Vladivostok, Russia

Dr. Simon Dowell, Science Director, Chester Zoo, UK

Dr. Mário Gabriel Santiago dos Santos, Universidade de Trás-os-Montes e Alto Douro,

Quinta de Prados, Vila Real, Portugal

Dr. Grant Connette, Smithsonian Institution, Royal, VA, USA

Dr. M. Zafar-ul Islam, Prince Saud Al Faisal Wildlife Research Center, Taif, Saudi Arabia

Mammals

Dr. Giovanni Amori, CNR - Institute of Ecosystem Studies, Rome, Italy

Dr. Anwaruddin Chowdhury, Guwahati, India

Dr. David Mallon, Zoological Society of London, UK

Dr. Shomita Mukherjee, SACON, Coimbatore, Tamil Nadu, India

Dr. Angie Appel, Wild Cat Network, Germany

Dr. P.O. Nameer, Kerala Agricultural University, Thrissur, Kerala, India

Dr. Ian Redmond, UNEP Convention on Migratory Species, Lansdown, UK

Dr. Heidi S. Riddle, Riddle's Elephant and Wildlife Sanctuary, Arkansas, USA

Dr. Karin Schwartz, George Mason University, Fairfax, Virginia.

Dr. Lala A.K. Singh, Bhubaneswar, Orissa, India

Dr. Mewa Singh, Mysore University, Mysore, India

Dr. Paul Racey, University of Exeter, Devon, UK

Dr. Honnavalli N. Kumara, SACON, Anaikatty P.O., Coimbatore, Tamil Nadu, India

Dr. Nishith Dharaiya, HNG University, Patan, Gujarat, India

Dr. Spartaco Gippoliti, Socio Onorario Società Italiana per la Storia della Fauna "Giuseppe

Altobello", Rome, Italy

Dr. Justus Joshua, Green Future Foundation, Tiruchirapalli, Tamil Nadu, India

Dr. H. Raghuram, The American College, Madurai, Tamil Nadu, India

Dr. Paul Bates, Harison Institute, Kent, UK

Dr. Jim Sanderson, Small Wild Cat Conservation Foundation, Hartford, USA

Dr. Dan Challender, University of Kent, Canterbury, UK

Dr. David Mallon, Manchester Metropolitan University, Derbyshire, UK

Dr. Brian L. Cypher, California State University-Stanislaus, Bakersfield, CA

Dr. S.S. Talmale, Zoological Survey of India, Pune, Maharashtra, India

Prof. Karan Bahadur Shah, Budhanilakantha Municipality, Kathmandu, Nepal

Dr. Susan Cheyne, Borneo Nature Foundation International, Palangkaraja, Indonesia

Dr. Hemanta Kafley, Wildlife Sciences, Tarleton State University, Texas, USA

\section{Other Disciplines}

Dr. Aniruddha Belsare, Columbia MO 65203, USA (Veterinary)

Dr. Mandar S. Paingankar, University of Pune, Pune, Maharashtra, India (Molecular)

Dr. Jack Tordoff, Critical Ecosystem Partnership Fund, Arlington, USA (Communities)

Dr. Ulrike Streicher, University of Oregon, Eugene, USA (Veterinary)

Dr. Hari Balasubramanian, EcoAdvisors, Nova Scotia, Canada (Communities)

Dr. Rayanna Hellem Santos Bezerra, Universidade Federal de Sergipe, São Cristóvão, Brazil

Dr. Jamie R. Wood, Landcare Research, Canterbury, New Zealand

Dr. Wendy Collinson-Jonker, Endangered Wildlife Trust, Gauteng, South Africa

Dr. Rajeshkumar G. Jani, Anand Agricultural University, Anand, Gujarat, India

Dr. O.N. Tiwari, Senior Scientist, ICAR-Indian Agricultural Research Institute (IARI), New

Delhi, India

Dr. L.D. Singla, Guru Angad Dev Veterinary and Animal Sciences University, Ludhiana, India

Dr. Rupika S. Rajakaruna, University of Peradeniya, Peradeniya, Sri Lanka

Dr. Bahar Baviskar, Wild-CER, Nagpur, Maharashtra 440013, India

Reviewers 2018-2020

Due to pausity of space, the list of reviewers for $2018-2020$ is available online.

The opinions expressed by the authors do not reflect the views of the Journal of Threatened Taxa, Wildlife Information Liaison Development Society, Zoo Outreach Organization, or any of the partners. The journal, the publisher, the host, and the partners are not responsible for the accuracy of the political boundaries shown in the maps by the authors.

Journal of Threatened Taxa is indexed/abstracted in Bibliography of Systematic Mycology, Biological Abstracts, BIOSIS Previews, CAB Abstracts, EBSCO, Google Scholar, Index Copernicus, Index Fungorum, JournalSeek, National Academy of Agricultural Sciences, NewJour, OCLC WorldCat, SCOPUS, Stanford University Libraries, Virtual Library of Biology, Zoological Records.

NAAS rating (India) 5.64
Print copies of the Journal are available at cost. Write to:

The Managing Editor, JoTT,

c/o Wildlife Information Liaison Development Society,

No. 12, Thiruvannamalai Nagar, Saravanampatti - Kalapatti Road,

Saravanampatti, Coimbatore, Tamil Nadu 641035, India

ravi@threatenedtaxa.org 


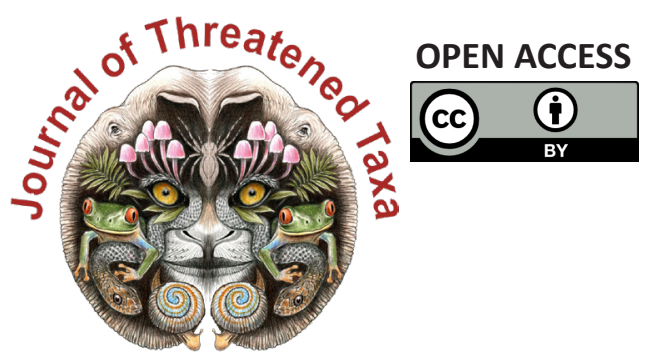

www.threatenedtaxa.org

The Journal of Threatened Taxa (JoTT) is dedicated to building evidence for conservation globally by publishing peer-reviewed articles online every month at a reasonably rapid rate at www.threatenedtaxa.org. All articles published in JoTT are registered under Creative Commons Attribution 4.0 International License unless otherwise mentioned. JoTT allows allows unrestricted use, reproduction, and distribution of articles in any medium by providing adequate credit to the author(s) and the source of publication.

ISSN 0974-7907 (Online) I ISSN $0974-7893$ (Print)

\section{November 2021 | Vol. 13 | No. 13 | Pages: 19887-20142 \\ Date of Publication: 26 November 2021 (Online \& Print) DOI: 10.11609/jott.2021.13.13.19887-20142}

\section{Article}

An inventory of geometrid moths (Lepidoptera: Geometroidea: Geometridae) of KalakadMundanthurai Tiger Reserve, India

- Geetha Iyer, Dieter Stüning \& Sanjay Sondhi, Pp. 19887-19920

\section{Communications}

Roadkills of Lowland Tapir Tapirus terrestris (Mammalia: Perissodactyla: Tapiridae) in one of its last refuges in the Atlantic Forest

- Aureo Banhos, Andressa Gatti, Marcelo Renan de Deus Santos, Leonardo Merçon,

Ilka Westermeyer, Natália Carneiro Ardente, Luis Francisco Oliveira Pereira Gonzaga, Lucas Mendes Barreto, Lucas Damásio, Tomas Lima Rocha, Vitor Roberto Schettino, Renata Valls, Helena Godoy Bergallo, Marcos Vinicius Freitas Silva, Athelson Stefanon Bittencourt, Danielle de Oliveira Moreira \& Ana Carolina Srbek-Araujo, Pp. 19921-19929

Scientific contributions and learning experiences of citizen volunteers with a small cat project in Sanjay Gandhi National Park, Mumbai, India

- Shomita Mukherjee, R. Nandini, P.V. Karunakaran \& Nayan Khanolkar, Pp. 19930-19936

Seasonal food preferences and group activity pattern of Blackbuck Antilope cervicapra (L., 1758) (Mammalia: Cetartiodactyla: Bovidae) in a semi-arid region of western Haryana, India

- Vikram Delu, Dharambir Singh, Sumit Dookia, Priya \& Kiran, Pp. 19937-19947

Studies on the habitats of Grey Francolin Francolinus pondicerianus (J.F. Gmelin, 1789) (Galliformes: Phasianidae) in northern districts of Tamil Nadu, India

- M. Pandian, Pp. 19948-19955

Recovery of vulture population in roosting and scavenging areas of Bastar and Bijapur, Chhattisgarh, India

- Sushil Kumar Dutta, Muntaz Khan, P.R.S. Nagi, Santosh Durgam \& Surabhi Dutta, Pp. 19956-19963

A geographical assessment of Chariganga and Arpara Beel (wetlands) of Nadia, West Bengal as a habitat of wetland birds

- Mehedi Hasan Mandal, Arindam Roy \& Giyasuddin Siddique, Pp. 19964-19975

Phenotypic plasticity in Barilius vagra (Hamilton, 1822) (Teleostei: Danionidae) from two geographically distinct river basins of Indian Himalaya

- Sumit Kumar, Sharali Sharma \& Deepak Singh, Pp. 19976-19984

Taxonomic notes, a new species, and a key to Indian species of the click beetle genus Cryptalaus Ôhira, 1967 (Coleoptera: Elateridae: Agrypninae)

- Harshad Parekar \& Amol Patwardhan, Pp. 19985-19999

Niche overlap of benthic macrofauna in a tropical estuary: diurnal variation

- Mário Herculano de Oliveira, Lidiane Gomes de Lima, Caroline Stefani da Silva Lima, Jéssica de Oliveira Lima Gomes, Franciely Ferreira Paiva, Graciele de Barros, Carlinda Railly Medeiros \& Joseline Molozzi, Pp. 20000-20010

Diversity of aquatic insects and biomonitoring of water quality in the upper Ganga River, a Ramsar site: a preliminary assessment

- Kritish De, Arkojyoti Sarkar, Kritika Singh, Virendra Prasad Uniyal, Jeyaraj Antony Johnson \& Syed Ainul Hussain, Pp. 20011-20018

Patterns of forest cover loss in the terrestrial Key Biodiversity Areas in the Philippines: critical habitat conservation priorities

- Bernard Peter O. Daipan, Pp. 20019-20032

The woody flora of Shettihalli Wildlife Sanctuary, central Western Ghats of Karnataka, India - A checklist

- Kanda Naveen Babu, Kurian Ayushi, Vincy K. Wilson, Narayanan Ayyappan \&

Narayanaswamy Parthasarathy, Pp. 20033-20055

Reproductive biology of Ophiorrhiza caudata C.E.C.Fisch. (Rubiaceae), an endemic and endangered creeping perennial herb of the Western Ghats, India

- Maria Theresa, Appukuttan Kamalabai Sreekala \& Jayalakshmi Mohanlal, Pp. 20056-20065
Short Communications

Successful rescue, medical management, rehabilitation, and translocation of a Red Panda Ailurus fulgens (Mammalia: Carnivora: Ailuridae) in Arunachal Pradesh, India - Jahan Ahmed, Sorang Tadap, Millo Tasser, Koj Rinya, Nekibuddin Ahmed \& Sunil Kyarong, Pp. 20066-20071

A rare photographic record of Eurasian Otter Lutra lutra with a note on its habitat from the Bhagirathi Basin, western Himalaya, India

- Ranjana Pal, Aashna Sharma, Vineet Kumar Dubey, Tapajit Bhattacharya, Jeyaraj Antony Johnson, Kuppusamy Sivakumar \& Sambandam Sathyakumar, Pp. 20072-20077

The first record of Medog Gliding Frog Rhacophorus translineatus Wu, 1977 (Anura: Rhacophoridae) from Chhukha District, Bhutan

- Sonam Lhendup \& Bal Krishna Koirala, Pp. 20078-20083

First record of a freshwater crab, Maydelliathelphusa masoniana (Henderson, 1893) (Decapoda: Brachyura: Gecarcinucidae) from West Bengal, India

- Ram Krishna Das, Pp. 20084-20089

Butterflies of Amrabad Tiger Reserve, Telangana, India

- Deepa Jaiswal, B. Bharath, M. Karuthapandi, Shrikant Jadhav, S. Prabakaran \& S. Rehanuma Sulthana, Pp. 20090-20097

An enumeration of the flowering plants of Kyongnosla Alpine Sanctuary in eastern Sikkim, India

- Sudhansu Sekhar Dash, Subhajit Lahiri \& Ashiho Asoshii Mao, Pp. 20098-20117

A new record of psychrotrophic Paecilomyces formosus (Eurotiales: Ascomycota) from India: morphological and molecular characterization

- Skarma Nonzom \& Geeta Sumbali, Pp. 20118-20123

Notes

Study on incidence and pathology of gastrointestinal parasitic infections in Nilgai Boselaphus tragocamelus in Hisar, Haryana, India

- Maneesh Sharma, B.L. Jangir, D. Lather, G.A. Chandratre, V. Nehra, K.K. Jakhar \& G. Narang, Pp. 20124-20127

An unusual vocalization of Brown Hawk-Owl Ninox scutulata (Raffles, 1822) (Aves:

Strigiformes: Strigidae) recorded from Kerala, India

- Riju P. Nair \& Shine Raj Tholkudiyil, Pp. 20128-20129

New distribution data on the genus Maripanthus Maddison, 2020 (Araneae: Salticidae) from southern India

- A. Asima, John T.D. Caleb, Dhruv A. Prajapati \& G. Prasad, Pp. 20130-20132

On the IUCN status of Boesenbergia albolutea and B. rubrolutea (Zingiberaceae) and typification of $B$. rubrolutea

- K. Aishwarya \& M. Sabu, Pp. 20133-20135

New records of mass seeding Cephalostachyum latifolium Munro (Poaceae) along the midelevation broadleaved forest of Sarpang district, Bhutan

- Jigme Tenzin, Sangay Nidup \& Dago Dorji, Pp. 20136-20139

Response

If habitat heterogeneity is effective for conservation of butterflies in urban landscapes of Delhi, India?' Unethical publication based on data manipulation

- Sanjay Keshari Das \& Rita Singh, Pp. 20140-20142

Publisher \& Host
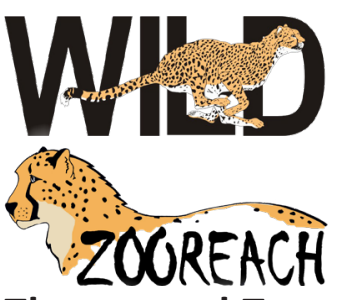

Threatened Taxa 